\title{
Analysis of curriculum processes for the development of competencies in engineering education
}

\author{
Ana María Graffigna Vaggione, Lucía Mabel Ghilardi, and María Amelin \\ Dávila Zarracán*
}

doi: http://dx.doi.org/10.18543/tjhe-7(2)-2020pp25-42

Received: 27 December 2019

Accepted: 4 March 2020

\begin{abstract}
This work presents the advances being made on a research project addressing curriculum processes for the development of competencies at the San Juan National University's Faculty of Engineering (Argentina) in the framework of institutional policies that seek to make its programs of study appropriate for the second generation of accreditation standards. This is an exploratory, descriptive and interpretative study that is currently in the analytic phase, during which time we have carried out a characterization of the study plans currently in force for seven engineering programs in place at the university. In this sense, we describe both the institutional transformation related to the creation of accreditation standards and the perspectives of institutional actors as regards the curriculum design of the San Juan National University Faculty of Engineering's programs, analyzing the institutional dynamic that emerges from said process.
\end{abstract}

Keywords: Curriculum; competencies; engineering; higher education; study plan.

* Ana María Graffigna Vaggione (amgraffigna@unsj.edu.ar) is Professor in Psychology and Educational Sciences in the Faculty of Engineering, San Juan National University (Argentina).

* Lucía Mabel Ghilardi (luciaghilardi@gmail.com) is Professor in Psychology and Educational Sciences in the Faculty of Engineering, San Juan National University (Argentina).

* María Amelin Davila Zarracán (amelin.dz@gmail.com) works as Psychologist and University Teaching Specialist in the Faculty of Engineering, San Juan National University (Argentina).

More information about the authors is available at the end of this article. 


\section{Introduction}

In the 1990s, interest in thinking about Curricula based on Competencies emerged in both national and international circles. This challenge is presented at all educational levels and implies analyzing the proposal, unraveling the conceptions of its different meanings and critically valuing its contributions, limitations and suppositions. The implementation of this curricular modality entails a transition from a model centered upon teaching to a model centered upon student learning, allowing students to become aware of knowledge, procedures and values for problem-solving through metacognitive capacities that permit them to reflect consciously on, plan, supervise, regulate and evaluate strategies involved in learning. Likewise, it implies know-how, being able to put into practice cognitive resources with flexibility in interaction with the subject, with the intervention of the moral conscious, in the sense that it supposes reflection on the social and ethical consequences of one's own actions.

In the world of engineering instruction, the Ibero-American Association of Engineering Education (ASIBEI), created in 1997 in response to the need to strengthen engineering both globally and internationally, has as its main objective "to promote the exchange of experiences between universities and the development of engineering education in each country, as well as to lay the groundwork on specific topics in order to establish strategies for improvement". In 2013, representatives from engineering institutions around Ibero-America gathered for ASIBEI's General Assembly in Valparaiso, Chile and agreed to propose, as common themes, competencies for graduation in order to facilitate regional integration and academic exchange.

There is consensus insomuch as all engineers must not only know, but also possess know-how. This know-how does not come from mere acquisition of knowledge but rather is the result of putting into practice a complex structure of knowledge, abilities, skills, etc. that should be recognized expressly in the learning process and as such the pedagogical proposal should include activities that allow for it development. Working with competencies, or intentionally integrating competencies, implies a framework that facilitates the well-adapted and efficient selection and teaching of contents. ${ }^{1}$

In Argentina, universities are responsible for awarding undergraduate degrees, while the National Ministry of Education is responsible for

${ }^{1}$ Roberto Giordano-Lerena et al., Perfil del ingeniero Iberoamericano, formación de profesores y desarrollo tecnológico e innovación (Bogotá: ASIBEI, 2016), 17. 
publicly recognizing and validating them at the national level. The Law of Higher Education (LES) establishes in article 43 that those degrees whose practice affects public interest must be accredited by the National Commission of University Evaluation and Accreditation (CONEAU). This accreditation implies periodic assessments of study plans and their development and evolution in line with previously agreed upon standards. These standards are established by academic commissions for each degree, councils of deans from both public and private universities, the National Interuniversity Council (CIN) and the corresponding CONEAU technical teams.

In October 2018, almost two decades after the first call for accreditation for Engineering programs, and based on evaluative reflection of the processes already carried out, the Federal Council of Engineering Deans (CONFEDI) presented a second generation of accreditation standards for undergraduate programs. This second generation contains a description of the referential framework and provides a set of common curricular conditions for engineering programs, including a graduate profile, general competencies for graduation, curricular structure and both minimum and general criteria. Subsequently, reserve activities, specific competencies and knowledge descriptors are indicated for 25 Engineering degrees (complete programs). ${ }^{2}$

\section{Theoretical framework}

In order to address the implementation of competencies in Higher Education, it is necessary to review curriculum design from its formulation itself, with the definition of graduation profiles and, more precisely, the inner workings of each course with their corresponding objectives, contents, modalities of instruction and systems of evaluation. Creating a study plan oriented towards the acquisition of graduation competencies challenges academic institutions to consider both new strategies for the selection and hierarchical organization of contents and new teaching proposals which focus classroom practice on student-centered learning. In addition, institutions are challenged to come up with strategies for the articulation and integration of areas or groupings of courses within each study plan.

${ }^{2}$ CONFEDI, Propuesta de Estándares de Segunda Generación para la acreditación de carreras de Ingeniería en la República Argentina "Libro Rojo De Confedi" (UFASTA Ediciones, 2018), 25-50. 
This proposal means that curriculum is the tool for communicating to students the educational offerings available to them, providing a specific version of the professional profile legitimized by the institutional culture, in conjunction with the formal requirements of the undergraduate education.

Besides the learning of specific concepts, the term competency implies the acquisition of values and abilities necessary to be able to practice responsibly in different professional situations. This means linking academic life with the social context and workplace.

Tobón defines competencies as "integral actions of people to activities and context problems with continuous improvement, ethics and suitability, as they articulate knowledges (know to be, know to coexist, know to know, and know to do) to handling external context situations, assuming the changes and uncertainty with autonomy and creativity". 3

Professional competencies, as taken from the contributions of Perrenoud ${ }^{4}$ and Le Boterf ${ }^{5}$ are integrated capacities connected to both theoretical and empirical knowledge, contextualized in the professional world, that integrate ethics and values. The Ibero-American Association of Engineering Education (ASIBEI) defines them as “... the capacity to effectively link a set of schemes (mental structures) and values, allowing for the mobilization (making available) of knowledge, in a certain context and with the objective of resolving professional situations". ${ }^{6}$

According to this proposal, in the world of university education, competencies may be either general or specific. General competencies are those which are necessary in order to ensure graduate profiles and which are common to all programs of study. Specific competencies are those that are reserved only for compliance with a specific degree program at an academic institution. The development of both (general and specific) can be carried out in the context of curricular activities or in the workplace, in extracurricular activities or as citizen action.

Ten general competencies are proposed, divided into two subgroups. The first is the set of technological general competencies, while the second includes the social, political and attitudinal general competencies.

${ }^{3}$ SergioTobón,Integral Formation and Competencies Complex thinking, curriculum, teaching and assessment (Lake Mary USA: Kresearch, 2016), 44.

${ }^{4}$ Philippe Perrenoud, Diez nuevas competencias para enseñar (Barcelona: Graó, 2004), $7-15$.

${ }^{5}$ Guy Le Boterf, Ingeniería de las competencias (Barcelona: Ediciones Gestión S.A., 2001).

${ }^{6}$ Giordano-Lerena, Perfil del ingeniero Iberoamericano, 22. 
- Technological competencies

1. Identify, formulate and resolve engineering problems.

2. Ideate, design and develop engineering projects.

3. Arrange, plan, execute and control engineering projects.

4. Effectively utilize application techniques and tools in engineering.

5. Contribute to the generation of technological developments and/or technological innovations.

- Social, political and attitudinal competencies

6. Perform effectively as part of a team.

7. Communicate effectively.

8. Act ethically, with professional responsibility and social commitment, considering the economic, social and environmental impact of one's activity in the local and global context.

9. Learn continuously and autonomously.

10. Act with entrepreneurial spirit.

The set of common curricular conditions for all engineering degree programs also requires a description of the curricular structure for study plans. These plans must be organized in accordance with the following areas: Basic Engineering Sciences, Basic Technologies, Applied Technologies and Complementary Sciences and Technologies. Basic Engineering Sciences involve the conceptual instruction that will form the base of more specific education, and address the competencies and knowledge descriptors necessary for initial compliance with study plan requirements. Basic Technologies include the scientific and technological competencies and knowledge descriptors of engineering phenomena which, based on the fundamental principles of the exact and natural sciences, are modeled for their management and use. Applied Technologies imply linking the previously mentioned areas in the design, calculation and projection of systems, components, processes or products and involve the competencies and knowledge descriptors of engineering design. Complementary Sciences and Technologies link Engineering practice with the social, historical, environmental and economic context in which it is inserted, in order to promote sustainable development. 


\section{Methodology}

The structural logic of this research project is mixed, quali-quantitative, and is oriented towards the development of a comprehensive study of the topic. ${ }^{7}$ It will involve intensive and in-depth analysis of several aspects of the same phenomenon and is part of the interpretive research design paradigm since its purpose is to describe and understand the curriculum design process by competencies in the Faculty of Engineering of the San Juan National University. A process of "intentional and systematic inquiry is proposed, aimed at gathering information to develop knowledge and explanations that allow us to understand, explain and, finally, transform the educational context". 8

The study's reach is exploratory as it is aimed at examining and obtaining information in a particular context. It is descriptive because it deals with characterizing specific situations in which the study phenomenon intervenes; and it is interpretive in that it links the results of the analysis of the different categories in order to understand the object. The setting selected is the Faculty of Engineering, within a historical and social context which currently is challenging it to develop a new model of curricular design. This need to carry out curricular revision disrupts current reality and mobilizes educational actors to get involved in the transformations, personally (in terms of how I see and carry out my practice), relationally (in terms of teaching teams, transversality of contents with courses preceding and following mine, relationships with authorities and with students, etc.) and with the macro context (in terms of educational policy and the state of the art of each scientific discipline).

Data arise from the systematization and analysis of curricular documents, minutes of academic commissions and meetings of the directive council; institutional regulations; curricula and surveys answered by teachers and students. Information was also obtained from the participant observation, the ethnographic interview and the analysis of documents because they constitute the best way to capture idiosyncratic and situational aspects in the context under investigation.

${ }^{7}$ Gloria Pérez Serrano, Investigación cualitativa. Métodos y Técnicas (Buenos Aires: Docencia, 2003).

${ }^{8}$ Pedro Gregorio Enriquez, El docente-investigador. Un mapa para explorar un territorio complejo (San Luis: Laboratorio de Alternativas Educativas, 2007). 


\section{Institutional initiatives for the adaptation to standards}

In its presentation of second generation standards for the accreditation of engineering programs, CONFEDI formalized the incorporation of a student-centered learning model oriented towards developing graduation competencies for Argentine engineers. It established both general and specific competencies for all of the Engineering degree programs in the country. It also proposed a training program for the teaching of engineering which takes up this referential framework and opened a call to educate institutional actors as mentors for all of the Faculties in the country. These mentors would accompany the processes of design and implementation of the curricular and institutional transformations necessary for adaptation to the new standards. In response to this call, the Faculty of Engineering at the San Juan National University participates with the integration of part of the teaching team from the Technical Educational University Center (CUTE) as educational agents in the program, with the participation of its Academic Secretary, a Department Chair, a Degree Coordinator and a CUTE professor.

\section{IV.1. Description of actions carried out}

The professional competencies development process related to the graduation profile was carried out in meetings with different institutional members.

In November 2017, CUTE, with Faculty authorities, brought together department chairs, degree directors, professors and students for the seminar "Challenges to Education through Competencies in Engineering". This seminar had as its objective to promote reflection on the current challenges facing engineering education in terms of teaching practices.

The training proposal was structured with a classroom-workshop methodology, that is, with the collective work of its participants, in order to replicate the teaching logic expected of professors.

During 2018, members of the CUTE team participated in meetings of the Teaching Advisory Council (CADE). Department chairs were asked to carry out a survey gathering the perspectives of their professors, students and alumni as regards the functioning of the current study plan in order to become aware of teaching dynamics currently being used and to make decisions for future modifications. As a result of these meetings, three instances of action were agreed upon and are presented in Table 1. 
Table 1

Institutional development proposal for adaptation to second generation standards

\begin{tabular}{|c|c|c|c|}
\hline ACTION & DESCRIPTION & $\begin{array}{l}\text { RESPONSIBLE } \\
\text { ENTITY }\end{array}$ & SCOPE \\
\hline \multicolumn{4}{|c|}{ 1st Instance: sensitization and training } \\
\hline $\begin{array}{l}\text { Diffusion of } \\
\text { Libro Rojo } \\
\text { CONFEDI/ } \\
\text { Proposal } \\
\text { of second } \\
\text { generation } \\
\text { standards }\end{array}$ & $\begin{array}{l}\text { - Publication on website and } \\
\text { digital media } \\
\text { - Cloister Meetings } \\
\text { - Broadcast Days }\end{array}$ & $\begin{array}{l}\text { Academic } \\
\text { and } \\
\text { Extension } \\
\text { Secretariat }\end{array}$ & Institutional \\
\hline $\begin{array}{l}\text { Teacher } \\
\text { training / } \\
\text { updating }\end{array}$ & $\begin{array}{l}\text { Design and implementation } \\
\text { of training proposals related } \\
\text { to the referential frameworks } \\
\text { of the new standards (ACE, } \\
\text { competencies, etc.) }\end{array}$ & CUTE & Institutional \\
\hline \multicolumn{4}{|c|}{ 2nd instance: Diagnosis } \\
\hline $\begin{array}{l}\text { Curriculum } \\
\text { analysis }\end{array}$ & $\begin{array}{l}\text { - Survey of opinions regarding } \\
\text { current training proposals } \\
\text { (teachers, students, graduates) } \\
\text { - Comparison of curricula } \\
\text { with the standards proposal. } \\
\text { Absence Identification, } \\
\text { reiterations, etc. } \\
\text { - Review of contents, time } \\
\text { loads, structure, etc. } \\
\text { - Evaluation of training } \\
\text { experiences and content that } \\
\text { promote skills for graduation. }\end{array}$ & $\begin{array}{l}\text { Department } \\
\text { Heads } \\
\text { Program } \\
\text { Coordination }\end{array}$ & $\begin{array}{l}\text { Department } \\
\text { Program }\end{array}$ \\
\hline $\begin{array}{l}\text { Identification } \\
\text { of resulting } \\
\text { problems }\end{array}$ & $\begin{array}{l}\text { - Regulatory Analysis } \\
\text { - Evaluation of operational } \\
\text { and functional conditions } \\
\text { (fewer hours in front of } \\
\text { students, academic regulation, } \\
\text { academic calendar regarding } \\
\text { course time) } \\
\text { - Estimation of necessary } \\
\text { resources. Management. }\end{array}$ & $\begin{array}{l}\text { Department } \\
\text { Heads } \\
\text { Program } \\
\text { Coordination }\end{array}$ & $\begin{array}{l}\text { Department } \\
\text { Program }\end{array}$ \\
\hline
\end{tabular}




\begin{tabular}{|c|c|c|c|}
\hline ACTION & DESCRIPTION & $\begin{array}{l}\text { RESPONSIBLE } \\
\text { ENTITY }\end{array}$ & SCOPE \\
\hline \multicolumn{4}{|c|}{ 3rd instance: Implementation } \\
\hline $\begin{array}{l}\text { Decision } \\
\text { making }\end{array}$ & $\begin{array}{l}\text { Formalization of curricular } \\
\text { adjustments (redesign or } \\
\text { modification of curricula) }\end{array}$ & $\begin{array}{l}\text { Department } \\
\text { Heads } \\
\text { Program } \\
\text { Coordination }\end{array}$ & $\begin{array}{l}\text { Department } \\
\text { Program }\end{array}$ \\
\hline $\begin{array}{l}\text { Design } \\
\text { strategies } \\
\text { adapted } \\
\text { to new } \\
\text { standards. }\end{array}$ & $\begin{array}{l}\text { - Content hierarchy based on } \\
\text { descriptors } \\
\text { - Articulation experiences } \\
\text { - Relate curricular activities } \\
\text { with specific skills. Articulated } \\
\text { disaggregation competitions. } \\
\text { - Integration of frames of } \\
\text { reference to the design of } \\
\text { formative and evaluation } \\
\text { experiences. } \\
\text { - Promote instances of } \\
\text { articulation between } \\
\text { programs, chairs, cycles, } \\
\text { institutions, etc. } \\
\text { - Promote the incorporation of } \\
\text { new resources from teaching } \\
\text { and evaluation (ICTs, rubrics } \\
\text {...) }\end{array}$ & $\begin{array}{l}\text { Department } \\
\text { Heads } \\
\text { Program } \\
\text { Coordination }\end{array}$ & $\begin{array}{l}\text { Department } \\
\text { Program }\end{array}$ \\
\hline $\begin{array}{l}\text { Development } \\
\text { of strategies } \\
\text { adapted } \\
\text { to new } \\
\text { standards. }\end{array}$ & $\begin{array}{l}\text { - Implementation of the } \\
\text { adaptation strategies } \\
\text { designed. } \\
\text { - Integration of frames of } \\
\text { reference to practices of } \\
\text { teaching and evaluation. }\end{array}$ & $\begin{array}{l}\text { Department } \\
\text { Heads } \\
\text { Program } \\
\text { Coordination }\end{array}$ & $\begin{array}{l}\text { Department } \\
\text { Program }\end{array}$ \\
\hline
\end{tabular}

Source: Our own creation.

These actions were established from November 2017 to the present day. The following have been carried out:

- The creation of a web space called "The Teaching of Engineering" which pulls together bibliographic information and advertisements regarding student-centered teaching.

- The design and administration of instruments for gathering opinions (surveys) from 11 Engineering programs (Mining Engineering, Food Engineering, Chemical Engineering, Industrial Engineering, 
Electronic Engineering, Bioengineering, Electrical Engineering, Electromechanical Engineering, Civil Engineering, Land Surveying and Mechanical Engineering) divided among three groups of actors: professors, students and alumni. The surveys were designed and administered digitally. Actors accessed the surveys in two ways, from their department chair and by means of a hyperlink available on the CUTE website.

- The design and implementation of a virtual course entitled "Current Challenges for Engineering Education". A virtual modality was chosen due to its accessibility for all of the School's faculty.

The development and implementation of this experience meant organizing the contents in modules with the following titles:

- Module I: Engineering in the present day

- Module II: New standards in Engineering Education

- Module III: Curricular Design and Competencies in Engineering

- Module IV: Reflections on learning in Engineering

- Module V: Evaluation in Engineering Education.

Each module is organized into three sections: one section of interaction that includes a discussion forum and space for questions; one work section that includes the general presentation of the course, activities, evaluations, and written and audiovisual bibliography and one section of visibility for course tutors and participants.

\section{IV.2. Analysis of the emerging dynamic of curricular processes}

To complete the analysis of curricular processes, professors were consulted about courses included in the study plan related to their own. This information allowed us to understand the functional relevance of courses in the study plan.

Functional or operative relevance refers to the relationships between courses established by those responsible for curricular development, going beyond those that are formally established as prerequisites in the study plan. Based on this systematization, four types of courses were identified, detailed below.

- Central courses: Courses chosen by more than $40 \%$ of professors as relating to their own 
- Peripheral courses: Courses chosen by between $20 \%$ and $39 \%$ of professors as relating to their own

- Atomized courses: Courses chosen by less than $20 \%$ of professors as relating to their own and as such make up small groups of courses (two or three) that function as an isolated nucleus

- Isolated courses: Courses not chosen by any professors

Figure 1 shows the proportion of courses of each type in study plans belonging to the degree programs participating in the survey is presented.

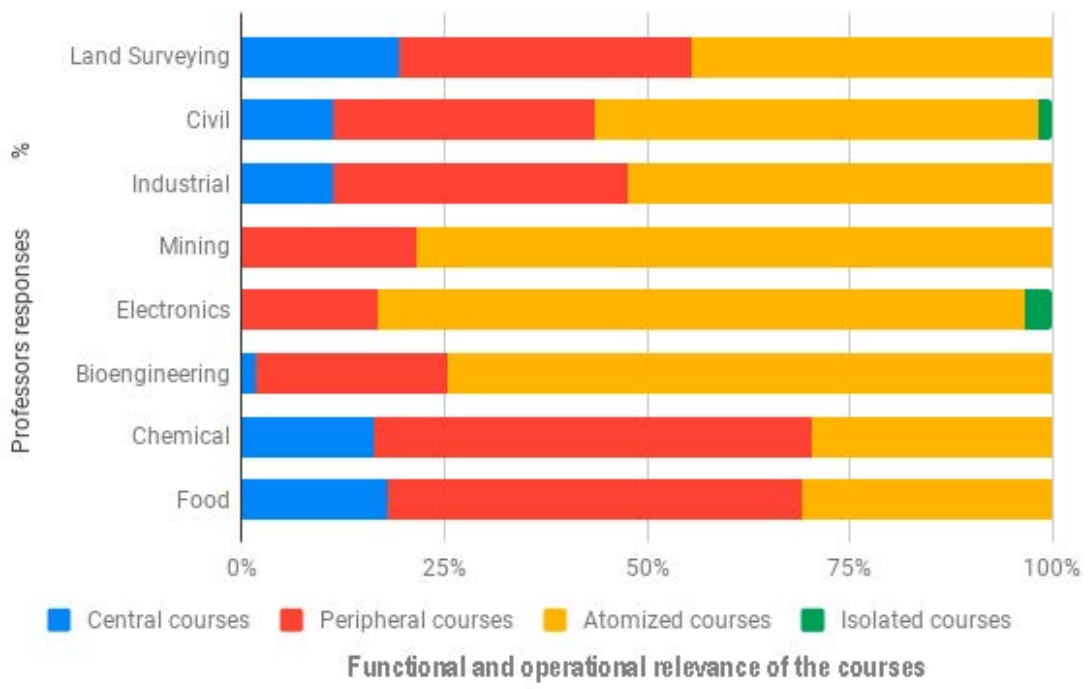

Figure 1

Proportion of courses in the study plan. Functional/operative relevance.

Source: Our own creation. Surveys administered to professors in March-July 2019

From the study carried out, it is possible to note several differences in terms of the functional structure of the different plans.

- Type 1 Programs: Those programs in which the number of central courses and peripheral courses exceeds $50 \%$ of the total courses in the study plan, such as Land Surveying, Chemical Engineering and Food Engineering. 
- Type 2 Programs: Those programs in which the number of central courses and peripheral courses is near $50 \%$ of the total courses in the study plan, while the rest are atomized courses. This is the case of Civil Engineering and Industrial Engineering.

- Type 3 Programs: Those programs in which the number of central courses and peripheral courses is near $25 \%$ of the total courses in the study plan, while the rest are atomized or isolated courses. This is the case of Mining Engineering,Electronic Engineering and Bioengineering.

If this categorization is joined together with the evolution of reenrollment in the degree programs mentioned, we can see that the type 2 educational proposals present the best rates of student retention with truly ascending curves. The curves belonging to the type 1 educational proposals are more or less stable, while the type 3 educational proposals show descending or fluctuating retention curves, as is depicted in Figure 2.

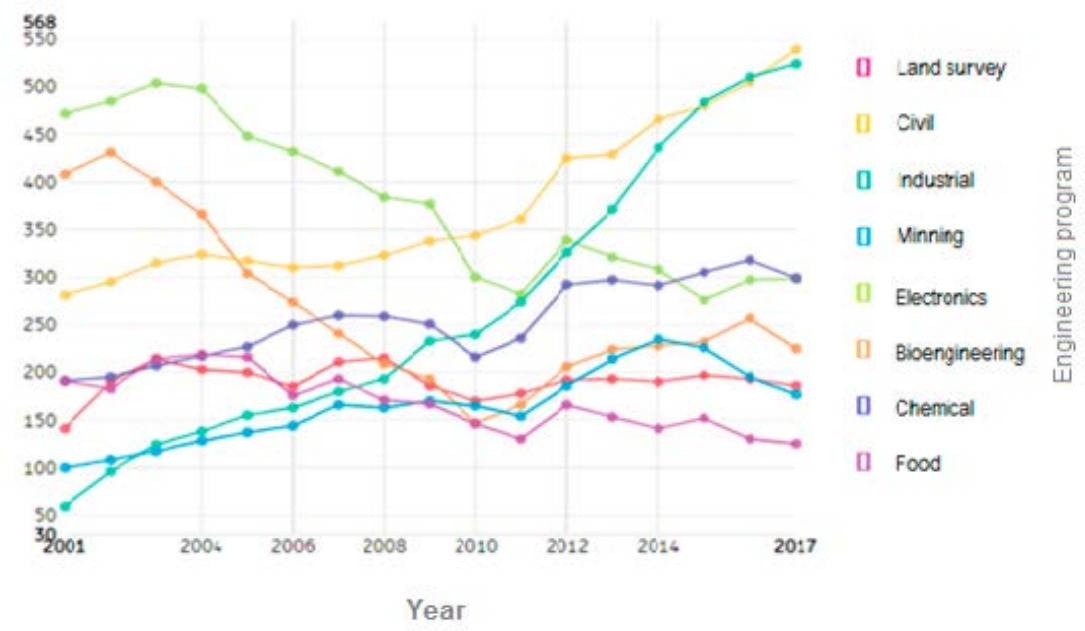

Figure 2

Evolution of reenrollment

Source: University Statistics Consultation System (SCEU) http://estadisticasuniversitarias. me.gov.ar/\#/home/2

Although this data is not categorical and the rates are also associated with other variables such as the amount of new enrollees and institutional 
efforts to foster retention (tutoring, office hours, workshops for new students), there seems to exist a relationship between the functioning of the curricular structure currently in force and the evolution of enrollment. These provisional statements show evidence of the need to work on the design of study plans with educational focus identified in courses of an integrating character, around which issues related to professional education can be addressed.

This analysis contributed to the design of curricular integration workshops that were carried out for the Bioengineering and Electronic Engineering programs ${ }^{9}$. These workshops focused on strengthening intercourse articulation policies and activities and led to the approval of a regimen of articulation activities that promote the development of new articulation proposals.

Student opinion, still in the process of being systematized, also coincided with the need to review prerequisite requirements.

"Prerequisites should be reviewed to prevent students from losing years of study and to minimize program desertion". (Survey 19 - Students)

"Review the order and prerequisite status of certain courses, like (...)". (Survey 57 - Students)

"Only establish strong prerequisite requirements for courses with similarities or with single use of content from the previous course". (Survey 205 - Students)

The aforementioned makes obvious the need to regularly review the internal structure of the study plans and to articulate between courses, placing competencies at the center of the design and proposing concrete decisions for each cycle.

\section{IV.3. Approach to general competencies}

In accordance with the current framework presented by CONFEDI, general competencies are divided into Technological and Social, Political and Attitudinal. In the surveys administered, answered by $56 \%$ of the professors, ${ }^{10}$ we collected opinions regarding the approach to general competencies in each of the degree programs analyzed. This study was carried out by degree program and also from an institutional perspective,

9 Lucía Ghilardi et al., "Desafíos de la integración curricular en la formación de bioingenieros" (Paper presented at 4th CADI and 10th CAEDI, CONFEDI, Córdoba, September 19,2018), https://cadi.org.ar/wp-content/uploads/2018/09/4_CADI_y_10_CAEDI_ paper_272.pdf

10466 professors were surveyed out of a total of 832 . 
integrating the totality of professor opinion, as general competencies are shared by all the engineering degree programs.

From the data, we can see that opinion is concentrated in greater quantities in the categories of "a lot" and "quite", which indicates that these competencies are considered to be central educational concepts in teaching practices. When professors were asked to give their opinion with respect to the way in which each course contributed to the development of these competencies, the results are available in Figure 3.

For the following analysis of Figures 3 and 4, the relative difference between the extreme categories of the scale ("A Lot" and "Little") will be considered.

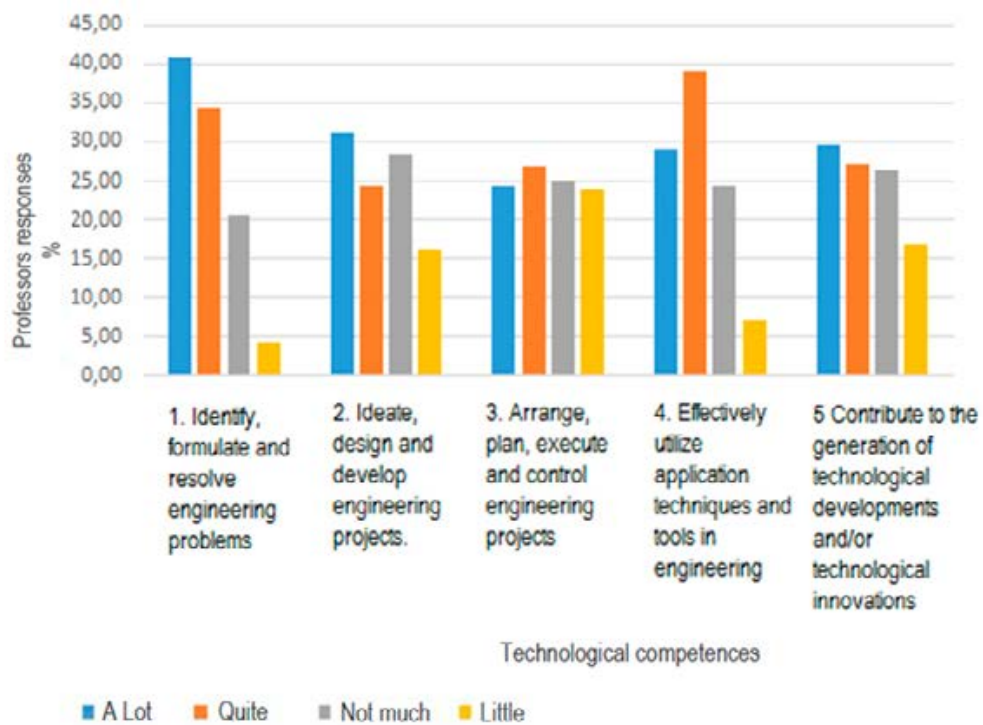

Figure 3

Approach to technological general competencies

Source: Our own creation. Surveys administered to professors in March-July 2019

As Figure 3 shows, competencies 1 (Identify, formulate and solve engineering problems) and 4 (Effectively use application techniques and tools in engineering) are those that obtain the highest rates in the "A Lot" 
category. These competencies have in common procedures that seem to be more algorithmic, related to the application of knowledge.

In contrast, competencies 2 (Ideate, design and develop engineering projects), 3 (Arrange, plan, execute and control engineering projects) and 5 (Contribute to the generation of technological developments and / or technological innovations) obtain more homogeneous distributions. It is significant for the latter, that the index obtained in the "Little" category is relatively high, since they refer to more complex skills related to creative processes such as devising or conceiving (competence 2), innovating (competence 5) and concretizing in the action, manage or execute (competence 3 )
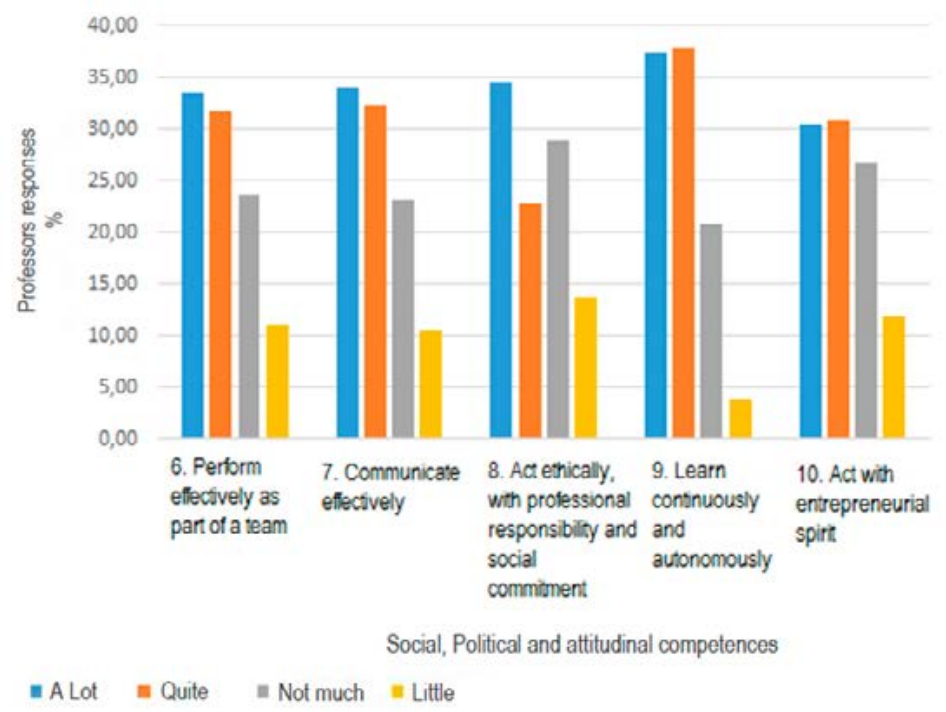

Figure 4

Approach to social, political and attitudinal general competencies

Source: Our own creation. Surveys administered to professors in March-July 2019

Regarding social, political and attitudinal competencies, it is noted that No. 9 presents more favorable development indicators, since most of the responses are located in the "A Lot" and "Quite" categories, while the "Little" is less than $5 \%$ of the responses. For the rest of the competencies of this type, the behavior is similar, since the "Little" category ranges from 10 
to $15 \%$ and the "A Lot" category ranges from 30 to $35 \%$. Competence 10 (acting with an entrepreneurial spirit) stands out for its homogeneity in the responses of the different actors. This data is consistent with the preceding analysis regarding technological competencies.

In summary, the general competencies that are most developed relate to the resolution of prototypical problems and to the application of knowledge, while those competencies that imply more "creative" processes, including design, development and innovation, appear less frequently.

The presence and transversality of the general competencies in the design, development and evaluation of study plans and curricular activities will continue to be analyzed in the current project and will be material for future research work.

\section{Preliminary conclusions and perspectives}

From the seminar "Challenges to Education through Competencies in Engineering" as a first encounter to CONFEDI's proposal, a reflexive process was encouraged and has helped to change representations of the term "competencies" on the part of institutional actors, integrating past work experiences and initiatives that were affected by institutional policies.

The establishment of an agenda agreed upon by department chairs and degree directors allowed all institutional actors to be involved in the CONFEDI proposal, generating shared responsibilities and a distribution of tasks and enabling commitment and autonomy in the different departments, all the while respecting each one's timeline.

Communication has been an important tool for defining action, allowing agreements to be made about underlying conceptions of the term "competency" and orienting work towards action. However, this is also a dimension that must be strengthened, as communication is fundamental to the development of any project of change and growth.

With respect to the distance education proposals, we note that they were made easily available to all professors, professors who generally do not attend in-person seminars offered by the Center. The course was recently opened and despite initial expectations, registration so far has been quite scarce. Publicity has been observed to be a difficulty. Though the course has been publicized through formal channels, such as the university's website, and informal channels, such as recommendations and social networks, the reach hoped for has not been achieved. Professors who have participated in the courses highlight the opportunity to become aware of new approaches and have begun 
to implement changes in their classroom practice, as initiatives emerging from the reflection activities proposed in the different modules.

Springing from CONFEDI's presentation of general approaches to curricular design for Engineering programs and from CUTE's proposals, some degree programs have started their own path, with strategies and actions uniquely theirs and where different degrees of completion of the transformation process currently coexist. There are few characteristics that allow us to collectively identify said paths.In general terms, curricular processes oriented towards the development of competencies have required the creation of mechanisms to foster the participation of professors, students and alumni, as well as the revision (through the use of different resources) of study plans, course articulation, and the selection and hierarchical organization of content.

\section{Bibliography}

CONFEDI. Propuesta de Estándares de Segunda Generación para la acreditación de carreras de Ingeniería en la República Argentina. Mar del Plata: UFASTA Ediciones, 2018.

Enriquez, Pedro Gregorio. El docente-investigador. Un mapa para explorar un territorio complejo. San Luis: Laboratorio de Alternativas Educativas, 2007.

Giordano-Lerena, Roberto, Juan José Echevarría, Fredi Paredes, Ana María de Mattos Rettl, Luis Alberto Gonzalez, and Miguel Ángel Sosa. Perfil del ingeniero Iberoamericano, formación de profesores y desarrollo tecnológico e innovación. Bogotá: ASIBEI, 2016.

Ghilardi, Lucía, Ana María Graffigna, María Elisa Pérez, and Juan Pablo Graffigna. "Desafíos de la integración curricular en la formación de bioingenieros." Paper presented at 4th Congreso Argentino de Ingeniería and 10th Congreso Argentino de Enseñanza de la Ingeniería, CONFEDI, Córdoba, September 2018. https:// cadi.org.ar/wp-content/uploads/2018/09/4_CADI_y_10_CAEDI_paper_272. pdf.

Le Boterf, Guy. Ingeniería de las competencias. Barcelona: Ediciones Gestión S.A, 2001.

Ley $\mathrm{N}^{\circ}$ 24521. Ley de Educación Superior. Boletín Oficial, Buenos Aires, Argentina, 1995.

Pérez Serrano, Gloria. Investigación cualitativa. Métodos y Técnicas. Buenos Aires: Docencia, 2003.

Perrenoud, Philippe.Diez nuevas competencias para enseñar. Barcelona: Graó, 2004.

Tobón, Sergio, Julio Herminio Pimienta Prieto, and Juan Antonio García Fraile. Secuencias didácticas: aprendizaje y evaluación de competencias. México: Pearson educación, 2010. 
Tobón, Sergio. Integral Formation and Competencies: Complex thinking, curriculum, teaching and assessment. Lake Mary (USA): Kresearch, 2016.

\section{About the authors:}

ANA MARÍA GRAFFIGNA VAGGIONE (amgraffigna@unsj.edu.ar) is head professor in the Technical Educational University Center,Faculty of Engineering, San Juan National University in Argentina. She is Psychopedagogue, Professor in Psychology and Educational Sciences and holds the rank of Master in Open and Distance Teaching and Learning, UNED, Spain. She leads work teams and is counselor at educational institutions on topics related to curriculum (design, development and evaluation), didactics (teaching, conceptions, and strategies), management, resource management, and interpersonal relationships. Her research interests focus on the improvement of teaching practices and implementation of innovative curricular proposals. Also she is a researcher on accreditation and institutional evaluation issues.

LUCÍA MABEL GHILARDI (luciaghilardi@gmail.com), psychopedagogue and Professor in Psychology and Educational Sciences, holds the ranks of head professor in the Technical Educational University Center,Faculty of Engineering, San Juan National University, Argentina. She has completed Master in Open and Distance Teaching and Learning, UNED, Spain. She leads research related to teaching practices and competence. Her main area of professional development is the educational field. Participation in scientific extension and dissemination activities and tasks as a compiler and / or author of publications and digital materials have also contributed to her experience around the reflection and study of the field of university education

MARÍA AMELINDAVILAZARRACÁN (amelin.dz@gmail.com) is a psychologist. She holds the ranks of head professor in the Technical Educational University Center, Faculty of Engineering, San Juan National University, Argentina. She holds the rank University Teaching Specialist. She is Professor in topics on work teams, social skills and human resources management. She is a researcher on topics related to teaching practices, and she is part of advisory work teams to improve teaching practices and educational institutional management. 


\title{
Analysis of curriculum processes for the development of competencies in engineering education
}

\author{
Ana María Graffigna Vaggione, Lucía Mabel Ghilardi, and María Amelin \\ Dávila Zarracán
}

doi: http://dx.doi.org/10.18543/tjhe-7(2)-2020pp25-42

\section{Copyright}

Copyright for this article is retained by the Publisher. It is an Open Access material that is free for full online access, download, storage, distribution, and or reuse in any medium only for noncommercial purposes and in compliance with any applicable copyright legislation, without prior permission from the Publisher or the author(s). In any case, proper acknowledgement of the original publication source must be made and any changes to the original work must be indicated clearly and in a manner that does not suggest the author's and or Publisher's endorsement whatsoever. Any other use of its content in any medium or format, now known or developed in the future, requires prior written permission of the copyright holder. 